\title{
Election fireworks
}

\author{
Now is the time for the research community to catch the attention of the next president \\ of the United States of America.
}

very New Year is an occasion for celebration, tinged with uncertainty. This year begins with financial markets in a particularly uncertain state, with no banker or citizen quite certain what fresh crisis lurks around the corner.

One thing we can be sure of is that all of us - from Maryland to Mozambique - will be hearing plenty during 2008 about an unusually open election for the next president of the United States. By this time next year, a new person will be set to assume that role, with major ramifications for scientists, as for everybody else.

Two major science-related issues - the rules for the conduct of embryonic stem-cell research, and society's response to climate change - are likely to feature fairly prominently in the run-up to the 4 November election. A host of secondary science and technology issues, such as agency budgets (see page 2) and whether the United States embarks on ambitious technology-policy initiatives in a bid to bolster its industrial competitiveness, will hinge on the election's outcome.

The process by which the two main parties select their candidates kicks off at the Iowa caucuses today. One interesting aspect is that several candidates offer approaches on these major issues that are not normally associated with their respective parties (see page 4).

This diversity is particularly striking among the Republicans, where the race remains extraordinarily wide open. For example, Senator John McCain (Republican, Arizona), unlike most in his party, has long championed decisive action to confront climate change. Two of his leading rivals, Mitt Romney and Rudy Giuliani, are supportive of federal funding for human embryonic stem-cell research. The leading candidates on the Democrat side are less diverse in their views. Whether that signifies a party that is healthily united or unhealthily moribund is for the voters to decide.

Election year offers a chance for scientists who aspire to a direct role in the political process to make their voices heard. Prompted by seven years of what they see as manipulation of scientific findings by the Bush administration, groups are trying to raise the profile of science in the upcoming campaign. An organization called Scientists and Engineers for America plans to launch a project tracking the science- and healthrelated votes of all members of Congress, plus challengers for their seats as well as the presidential candidates. Meanwhile, dozens of prominent scientific leaders have mounted a push for a 'Science Debate 2008', calling for a candidates' debate on science and technology issues.

It's a laudable idea, and even if the prospects of such a debate are rather remote, the campaign can play a useful role in raising the profile of important issues as the election unfolds. For it is now - while candidates are striving to win their respective party nominations - that their priorities, preferences and policy teams will be forged. Many researchers, of all political stripes, are deeply troubled by what they regard as the dysfunctional relationship between science and the outgoing Bush administration. There is a better chance of a more fruitful relationship arising next time round if scientists get involved early with the candidates, and with the energetic, nationwide public debate that already characterizes this most intense and open of primary seasons.

\section{Think about it}

\section{Reliable policy research is an underrated planning tool in developing countries.}

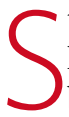
tep out onto any of Jakarta's city-centre highways during office hours and you will have no trouble crossing the road. This is because during peak times, a car journey that should take $20 \mathrm{~min}$ utes can take up to two hours, as drivers crawl along in the $30^{\circ} \mathrm{C}$ heat.

If Jakarta was the capital of a developed country, the authorities would have access to science-based advice on the policy options for easing the traffic from universities, state-sponsored research centres, industry, environmental groups and think-tanks. But in much of Africa, Asia, Latin America and the Middle East, such advice is rarely available for areas such as transport, agriculture, health, education and energy.

The lack of this capacity in Indonesia has recently been highlighted by the World Bank, which is considering a proposal to create a policy think-tank geared specifically to the needs of the many international agencies that are operating in the country.

The bank's entry into this sphere is welcome. A couple of decades ago, such agencies seemed uninterested in helping young researchers from developing countries to gain badly needed skills in policy analysis. As a result, the African Centre for Technology Studies in Nairobi, for example, began life in the spare bedroom of its founder, Calestous Juma. And Saleemul Huq, founder of the Bangladesh Centre for Advanced Studies, spent many a sleepless night worrying about how to pay his staff.

Today, these two centres are among the developing world's leading research-policy establishments, and their histories, along with those of Pakistan's Sustainable Development Policy Institute and Colombia's Alexander von Humboldt Institute, are described on page 8.

Two lessons stand out from these stories. The first is that each institution relied heavily on a driven, committed individual, who nurtured success where many would have expected failure. The second is that, despite the success of these particular institutions, impartial policy analysis is being held back in poor countries for want of either public or private sector support within these nations themselves.

Both governments and wealthy individuals in developing countries continue, on the whole, to regard sound policy analysis as a luxury that they cannot afford. They are wrong, and should join with donor nations and international agencies in backing the establishment of reliable, local organizations that can undertake it. 